\title{
Intravascular large B-cell lymphoma
}

\section{Manifestacje skórne wewnątrznaczyniowego chłoniaka z dużych komórek $B$}

\author{
Agnieszka Maria Odziomek, Piotr Jarliński, Ewelina Rebizak, Jolanta Węgłowska \\ Department of Dermatology and Paediatric Dermatology, Regional Specialized Hospital, Wrocław, Poland \\ Oddział Dermatologii z Pododdziałem Dermatologii Dziecięcej, Wojewódzki Szpital Specjalistyczny, Wrocław, Polska \\ Dermatol Rev/Przegl Dermatol 2021, 108, 46-5। \\ DOI: https://doi.org/l0.5। |4/dr.2021. 105893
}

\author{
CORRESPONDING AUTHOR/ \\ ADRES DO KORESPONDENCJI: \\ Agnieszka Maria Odziomek \\ Oddział Dermatogii \\ z Pododdziałem Dermatologii \\ Dziecięcej \\ Wojewódzki Szpital \\ Specjalistyczny \\ Wrocław, Polska \\ e-mail: agnieszka.odziomek@ \\ gmail.com
}

\begin{abstract}
Introduction. Intravascular large B-cell lymphoma is a rare type of lymphoma. The clinical presentation is dominated by skin lesions and central nervous system involvement.

Objective. This article presents the case of a cutaneous manifestations of intravascular large B-cell lymphoma.

Case report. A 64-year-old female was admitted to the dermatology department with widespread cutaneous telangiectasia. Seven months prior to the admission microcytic anaemia was diagnosed. The diagnosis of intravascular large B-cell lymphoma was based on histopathology. The patient died 3 days after introduction of chemotherapy.

Conclusions. Intravascular large B-cell lymphoma presents with a nonspecific clinical presentation that may mimic many dermatoses, requiring complex differential diagnosis.
\end{abstract}

\section{STRESZCZENIE}

Wprowadzenie. Wewnątrznaczyniowy chłoniak z dużych komórek B jest rzadkim typem chłoniaka. W obrazie klinicznym dominują zaburzenia neurologiczne i objawy skórne.

Cel pracy. Przedstawienie przypadku pacjentki z wewnątrznaczyniowym chłoniakiem z zajęciem skóry.

Opis przypadku. Kobieta 64-letnia została skierowana na oddział dermatologiczny z powodu rozległych teleangiektazji. Siedem miesięcy wcześniej stwierdzono u niej niedokrwistość mikrocytarną. Diagnozę postawiono na podstawie wyniku badania histopatologicznego skóry. Pacjentka zmarła 3 dni po rozpoczęciu chemioterapii.

Wnioski. Ze względu na stosunkowo częste występowanie objawów skórnych w przebiegu wewnątrznaczyniowego chłoniaka z dużych komórek B oraz nieswoisty obraz kliniczny przypominający wiele dermatoz wskazana jest złożona diagnostyka różnicowa.

Key words: intravascular B-cell lymphoma, B-cell lymphoma, IVBCL.

Słowa kluczowe: chłoniak wewnątrznaczyniowy, chłoniak z komórek B, IVBCL. 
Intravascular B-cell lymphoma (IVBCL) occurs rarely, with an estimated incidence of less than one per million [1, 2]. Initially, IVBCL was considered as a neoplasm of endothelial cells, but immunohistochemistry confirmed lymphoid genesis [3], in 2008 the disease was defined as intravascular B-cell lymphoma [4], although intravascular T- and NK-cell lymphoma was also discussed [5,6].

The pathophysiology of intravascular growth is explained by the lack of adhesion molecules (CD 29 (beta1 integrin) and CD 54 (ICAM-1)) and abnormalities of chemokines and chemokines receptor (CXCR3 at lymphocyte and CXCR at endothelial cell) etc. $[7,8]$. Lack of extravascular tissue infiltration may be due to the lack of expression of MMP-2 and MMP-9 (matrix metalloproteinase) [9].

Most of the IVLBCL data are case reports and retrospective analyses. The disease occurs in all age groups, the average age at diagnosis is 64 years; the disease is slightly more common in men [10]. There are no known risk factors [11].

The clinical presentation is non-specific, the symptoms result from the involvement of the vascular system of individual organs. There are two variants of clinical presentation in the literature: classical ("western" with involvement of the skin and the central nervous system) and Asian (with involvement of bone marrow, liver and spleen and hemophagocytic syndrome) $[1,4,12]$.

The incidence of skin symptoms is estimated at $17-39 \%[6,13]$. These include telangiectasia [14, 15], erythema induratum, painful nodules, annular lesions, maculopapular eruptions [16], panniculitis $[16,17]$, lymphedema of lower limbs [14], orange peel skin [18], purpura, petechiae, skin ulcers [16], senile angioma; sometimes skin lesions can mimic: Sweet syndrome, Kaposi sarcoma, morphea [19]. The cutaneous variant can be associated with better prognosis $[5,20]$, but some authors deny its existence [13].

In addition to skin lesions, involvement of the central nervous system $[2,15,21-24]$, gastrointestinal system $[25,26]$, respiratory system [27], urinary system [11, 23, 28], reproductive system [29], heart, joints [12], and eyes could occur [30].

The systemic symptoms are mainly fever $[5,31,32]$ and spleen enlargement $[12,33]$, while lymphadenopathy is not reported.

The most frequently observed deviations in laboratory tests are anaemia, thrombocytopenia, hypoalbuminaemia, increased level of ferritin and high activity of lactate dehydrogenase (LDH) $[12,31]$.

The disease is usually diagnosed in the advanced stage $[3,5]$, diagnosis in more than half of the cases is made posthumously [10]. Skin biopsy is an easy available diagnostic method, it is also recommend-

\section{WPROWADZENIE}

Wewnątrznaczyniowy chłoniak z dużych komórek B (intravascular B-cell lymphoma - IVBCL) jest rzadki, częstość jego występowania szacuje się na mniej niż jeden przypadek na milion [1, 2]. Pierwotnie uważano, że nowotwór rozwija się z komórek śródbłonka, dopiero na podstawie badań immunohistochemicznych udowodniono jego limfoidalne pochodzenie [3]. W 2008 r. zdefiniowano chorobę jako wewnątrznaczyniowego chłoniaka z dużych komórek B [4], choć opisywano także pojedyncze przypadki wewnątrznaczyniowych chłoniaków z limfocytów T i komórek NK [5, 6].

Patogeneza wzrostu wyłącznie wewnątrz światła naczyń jest tłumaczona m.in. brakiem cząsteczek adhezyjnych [CD29 ( $\beta_{1}$-integryny) i CD54 (ICAM-1)] oraz zaburzeniami chemokin i ich receptorów (CXCR3 w obrębie limfocytów i CXCL9 w obrębie komórek śródbłonka) [7, 8]. Za brak zdolności do infiltracji tkanek pozanaczyniowych może odpowiadać brak ekspresji metaloproteinaz macierzy MMP-2 i MMP-9 [9].

Większość danych dotyczących IVBCL to opisy przypadków i analizy retrospektywne. Choroba występuje we wszystkich grupach wiekowych. Średni wiek w momencie rozpoznania to 64 lata, nieco częściej chorują mężczyźni [10]. Nie są znane czynniki ryzyka [11].

Obraz kliniczny jest nieswoisty. Objawy wynikają z zajęcia układu naczyniowego poszczególnych narządów. W literaturze wyróżnia się dwie postacie: klasyczną (zachodnią) - z dominującymi objawami skórnymi i ze strony ośrodkowego układu nerwowego, azjatycką - z zajęciem szpiku kostnego, wątroby i śledziony oraz zespołem hemofagocytarnym $[1,4,12]$.

Częstość występowania objawów skórnych jest szacowana na 17-39\% [6, 13]. Można do nich zaliczyć: teleangiektazje $[14,15]$, rumień stwardniały, bolesne guzki, zmiany obrączkowate, osutkę plamisto-grudkową [16], zapalenie tkanki podskórnej [16, 17], obrzęk limfatyczny kończyn dolnych [14], zmiany typu skórki pomarańczy [18], plamicę, owrzodzenia [16], naczyniaki gwiaździste. Niekiedy zmiany mogą przypominać zespół Sweeta, mięsak Kaposiego lub twardzinę ograniczoną [19]. Postać przebiegająca wyłącznie z zajęciem skóry lepiej rokuje [5, 20], jednak niektórzy autorzy negują jej istnienie [13].

Poza zmianami skórnymi występują objawy ze strony ośrodkowego układu nerwowego [2, 15, 21-24], układu pokarmowego $[25,26]$, układu oddechowego [27], moczowego [11, 23, 28], narządów rodnych [29], serca, stawów [12], narządu wzroku [30].

Wśród objawów ogólnych dominuje podwyższona temperatura ciała $[5,31,32]$ i powiększenie śledziony 
ed for patients with suspected IVLBCL without skin lesions $[31,33,34]$. Sensitivity and specificity of random skin biopsy is estimated at $77.8 \%$ and $98.7 \%$ [35], not all authors agree with these values [36, 37], but most of authors claim that skin biopsy could accelerate diagnosis. The biopsied specimens should be obtained from fat-containing areas of the skin [31, 35]: thighs, abdomen, and the upper arm [35]. Due to the necessity of obtaining a sufficient amount of fat tissue, punch biopsy is not always sufficient to confirm the diagnosis [35]. A new diagnostic method is liquid biopsy that detects the typical mutations in slowly circulating DNA isolated from blood [38].

The prognosis is poor. The medial survival time is 7 months [10]. The treatment of choice is chemotherapy. Rituximab-based regimens are most effective [10].

\section{OBJECTIVE}

This paper presents a case of a cutaneous manifestation of intravascular large B-cell lymphoma in a 64-year-old woman.

\section{CASE REPORT}

A 64-year-old female was admitted to the dermatology department because of widespread cutaneous telangiectasia which had been persisting for 3 weeks prior to admission. The investigated patient negated any chronic disease. Because of a microcytic anaemia revealed in laboratory tests 7 months prior to admission the patient was diagnosed in the Internal Medicine Ward where laboratory tests, endoscopy of the gastrointestinal tract and abdominal and pelvic ultrasound were conducted. The findings were as follows: splenomegaly and high ESR (erythrocyte sedimentation rate) of $70 \mathrm{~mm} / \mathrm{h}$, then the patient was referred to the haematology outpatient clinic. Due to antinuclear antibodies (ANA $1: 1000$ ) the patient was also referred to the rheumatology department and a connective tissue disease was excluded and laboratory tests revealed an elevated ferritin level $(1221 \mu \mathrm{g} / \mathrm{l})$ and hypoalbuminemia $(24.5 \mathrm{~g} / \mathrm{l})$.

Considering progressing anaemia the patient was admitted to the Internal Medicine Ward again and laboratory tests, radiology studies (computed tomography (CT) of the thorax, CT of abdomen and pelvis, esophagogastroduodenoscopy, colonoscopy and breast ultrasonography) were conducted, no abnormalities were found. Because of widespread telangiectasia which appeared during hospitalization the patient was referred to the dermatology department.

On admission telangiectasias of the chest, lumbar region and thighs were seen, the skin was thickened, furthermore generalized oedema was observed (fig. 1). Microcytic anaemia (Hb $7.6 \mathrm{~g} / \mathrm{dl}$ ), throm-
$[12,33]$, natomiast powiększenie obwodowych węzłów chłonnych nie jest opisywane.

Najczęściej stwierdzane odchylenia w badaniach laboratoryjnych to niedokrwistość, małopłytkowość, hipoalbuminemia, duże stężenie ferrytyny oraz wysoka aktywność dehydrogenazy mleczanowej (lactate dehydrogenase - LDH) [12, 31].

Rozpoznanie ustala się zwykle w stadium zaawansowanym [3, 5], w ponad połowie przypadków pośmiertnie [10]. Łatwo dostępnym narzędziem diagnostycznym jest biopsja skóry, przez niektórych autorów zalecana w przypadku nieobecności zmian skórnych u osoby z podejrzeniem IVBCL [31, 33, 34]. Czułość i swoistość biopsji z przypadkowego miejsca są szacowane odpowiednio na 77,8\% i 98,7\% [35], nie wszyscy autorzy są zgodni co do tych wartości $[36,37]$, ale w ocenie większości wykonanie biopsji skóry może przyspieszyć rozpoznanie. Wycinek powinien być pobierany z miejsc, gdzie jest gruba tkanka tłuszczowa [31, 35] - z uda, ramienia, brzucha [35]. Ze względu na konieczność pobrania większej ilości tkanki tłuszczowej nie zawsze do postawienia diagnozy wystarcza materiał uzyskany metodą biopsji sztancowej [35]. Nową metodą diagnostyczną jest płynna biopsja, która pozwala ustalić obecność typowych mutacji w DNA wolno krążącym wyizolowanym z krwi obwodowej [38].

Rokowanie w IVBCL jest złe. Średni czas przeżycia od rozpoznania wynosi 7 miesięcy [10]. Leczeniem z wyboru jest chemioterapia. Najskuteczniejsze są schematy oparte na rytuksymabie [10].

\section{CEL PRACY}

Celem pracy jest przedstawienie przypadku zajęcia skóry w przebiegu wewnątrznaczyniowego chłoniaka z dużych komórek B u 64-letniej kobiety.

\section{OPIS PRZYPADKU}

Kobietę 64-letnią przyjęto na oddział dermatologiczny z powodu rozległych teleangiektazji, które wystąpiły 3 tygodnie przed hospitalizacją.

Pacjentka dotychczas nie chorowała przewlekle. Z powodu stwierdzonej przed 7 miesiącami niedokrwistości mikrocytarnej przeprowadzono diagnostykę na oddziale chorób wewnętrznych (badania laboratoryjne, endoskopowe przewodu pokarmowego i USG jamy brzusznej). Stwierdzono OB $70 \mathrm{~mm} / \mathrm{h}$ i powiększenie śledziony. Skierowano pacjentkę do poradni hematologicznej. Ze względu na wysokie miano przeciwciał przeciwjądrowych (ANA 1 : 1000) kobieta została skierowana na oddział reumatologiczny, gdzie wykluczono chorobę tkanki łącznej, a z odchyleń w badaniach laboratoryjnych stwierdzono wysokie stężenie ferrytyny $(1221 \mu \mathrm{g} / \mathrm{l}) \mathrm{i}$ hipoalbumi- 


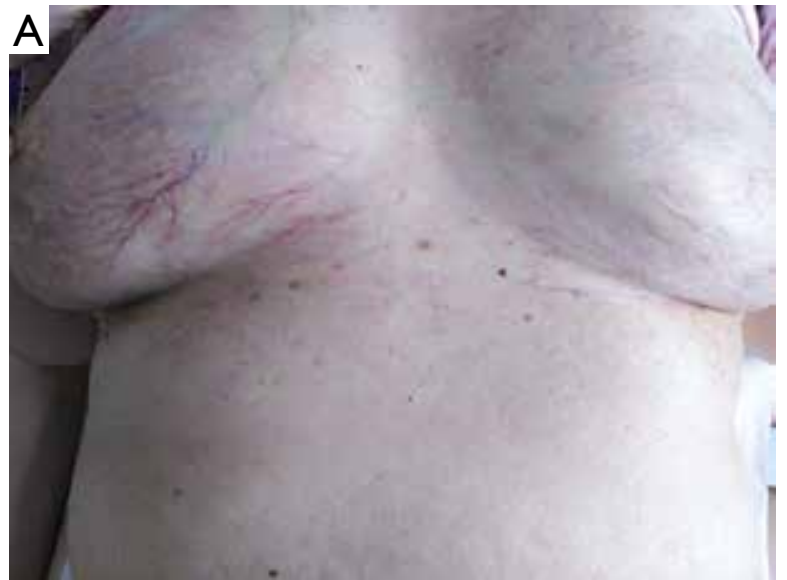

Figure I. Widespread cutaneous telangiectasia on the chest

Rycina I. Rozległe teleangiektazje na skórze klatki piersiowej

bocytopenia, high activity of LDH (1250 U/l) were found. During hospitalization punch skin biopsy and fine-needle aspiration biopsy of the bone marrow were performed. Bone marrow examination was correct, the skin biopsy confirmed diagnosis of intravascular large B-cell lymphoma (figs. 2-4). After confirmation of the diagnosis the patient was transferred to the haematology ward, she died 3 days after introducing of chemotherapy.

\section{CONCLUSIONS}

The rare incidence of intravascular lymphoma and non-specific clinical presentation are the reason for late diagnosis.

A relatively frequent incidence of skin lesions and imitation of many dermatoses require dermatologists to include it in the differential diagnosis, especially in the case of lack of response to treatment, concomitant symptoms and deviations in diagnostic tests.

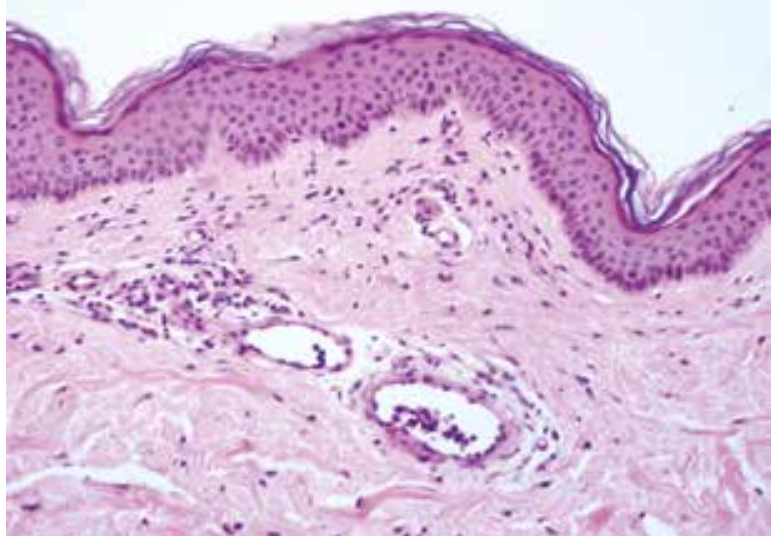

Figure 2. Lymphoid neoplastic cells within blood vessels (hematoxylin-eosin stain, 200x)

Rycina 2. Komórki nowotworowe w świetle naczyń (hematoksylina-eozyna, 200×)

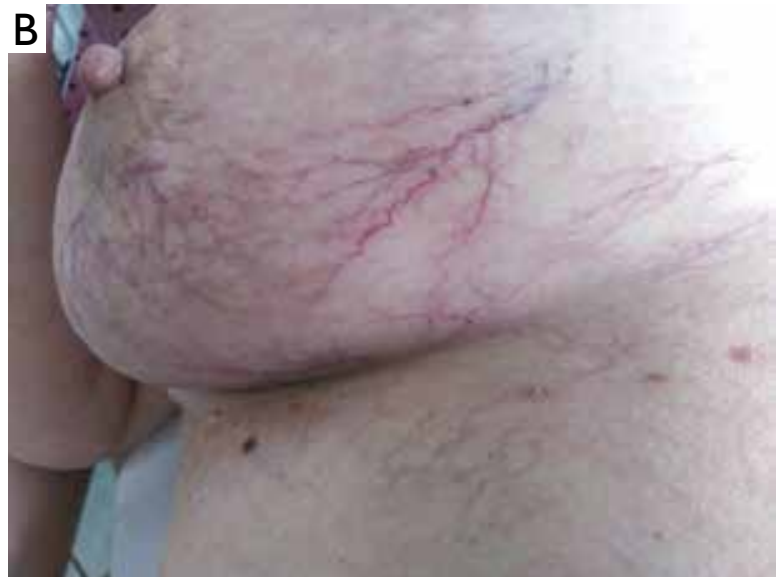

nemię $(24,5 \mathrm{~g} / 1)$. Z powodu narastającej niedokrwistości pacjentka została ponownie przyjęta na oddział chorób wewnętrznych, gdzie powtórzono diagnostykę endoskopową przewodu pokarmowego oraz poszerzono diagnostykę obrazową (CT jamy brzusznej i klatki piersiowej oraz USG sutków), nie stwierdzając odchyleń. W czasie hospitalizacji wystąpiły rozległe teleangiektazje, co przesądziło o skierowaniu na oddział dermatologiczny.

Podczas przyjęcia stwierdzono teleangiektazje na skórze klatki piersiowej, w okolicy lędźwiowej i na udach (ryc. 1). Skóra w miejscu zmian była nacieczona, ponadto występowały uogólnione obrzęki. Badania laboratoryjne wykazały niedokrwistość mikrocytarną ( $\mathrm{Hb} 7,6 \mathrm{~g} / \mathrm{dl}, \mathrm{MCV} 74,8$ fl) i małopłytkowość (74 tys./ $\mu 1)$, wysoką aktywność LDH (1250 U/1). Pobrano biopsję sztancową skóry i biopsję aspiracyjną szpiku kostnego - wynik biopsji szpiku kostnego był prawidłowy, biopsja skóry potwierdziła rozpoznanie wewnątrznaczyniowego chłoniaka $\mathrm{z}$ dużych komórek B (ryc. 2-4). Po potwierdzeniu rozpoznania przekazano pacjentkę na oddział hematologii, zmarła 3 dni po rozpoczęciu chemioterapii.

\section{WNIOSKI}

Rzadkie występowanie wewnątrznaczyniowego chłoniaka i jego nietypowy charakter są przyczyną późnego rozpoznawania choroby. Stosunkowo częste występowanie w jego przebiegu zmian skórnych i nieswoisty obraz kliniczny przypominający wiele dermatoz wymaga od dermatologów uwzględniania go w diagnostyce różnicowej, szczególnie w przypadku braku odpowiedzi na typowe leczenie i współistnienia innych objawów oraz odchyleń w badaniach dodatkowych. 


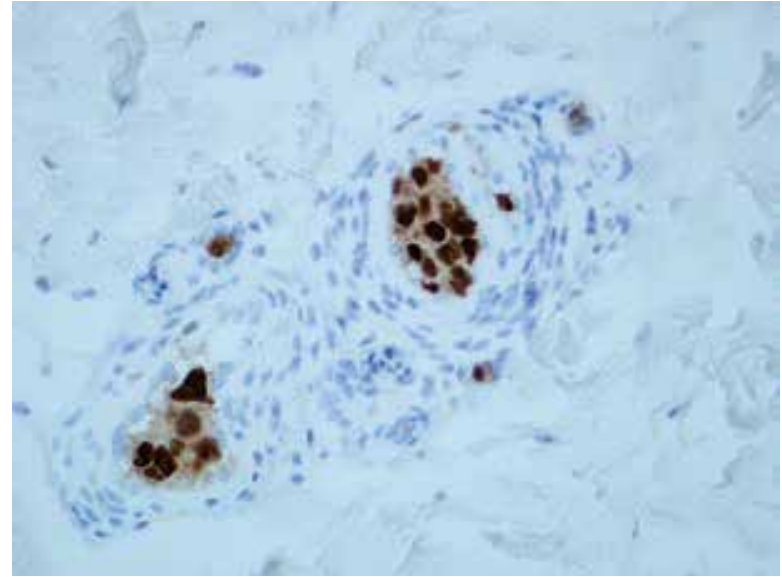

Figure 3. Lymphoid neoplastic cells within blood vessels. Immunohistochemical studies: CD20(+), Bcl2(+), MUMI (+), CD5(+/-), CD3(-), CDIO(-), CKEDI/AE3(-), PAX(+), Bcl6(+), CD56(-), CD246ALK(-), CD30(-), EBV(-) $(400 \times)$

Rycina 3. Komórki nowotworowe w świetle naczyń. Badanie immunohistochemiczne: CD20(+), Bcl2(+), MUMI (+), CD5(+/-), CD3(-), CDI0(-), CKEDI/AE3(-), PAX (+), BCI6(+), CD56(-), CD246ALK(-), CD30(-), EBV(-) (400x)

\section{CONFLICT OF INTEREST}

The authors declare no conflict of interest.

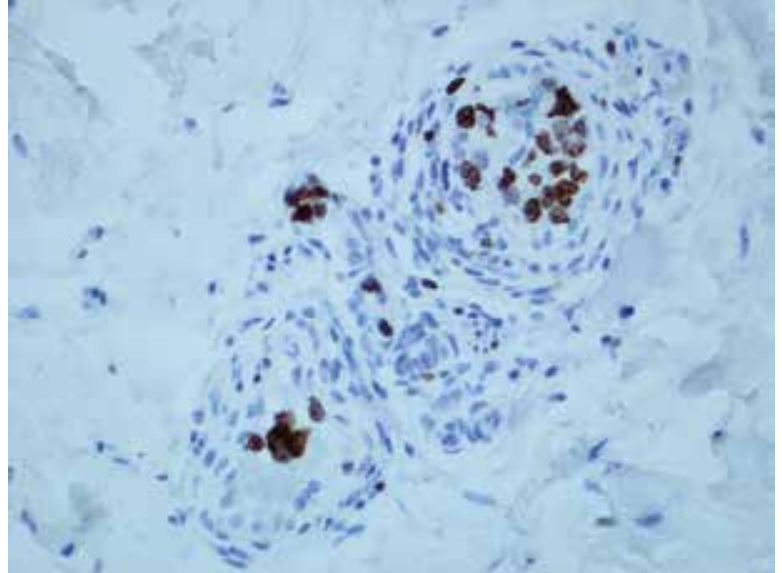

Figure 4. Lymphoid neoplastic cells seen within blood vessels. Ki67 of intravascular lymphoid cells 80\% (400x)

Rycina 4. Komórki nowotworowe w świetle naczyń. Ki67 populacji wewnątrznaczyniowej 80\% (400x)

\section{References}

Piśmiennictwo

1. Vásquez J., Romero V., Vilas P., Serra-Rexach J.A., Vidán M.T.: Progressive edemas and generalized telangiectasia: a presentation of intravascular B-cell lymphoma. Clin Case Rep 2014, 7, 2429-2432.

2. Kivity S., Shalmon B., Sidi Y.: Guillain-Barre syndrome: an unusual presentation of intravascular lymphoma. Isr Med Assoc J 2006, 8, 137-138.

3. Sheibani K., Battifora H., Winberg C.D., Burke S., Ben-Ezra J., Ellinger G.M., et al.: Further evidence that "malignant angioendotheliomatosis" is an angiotropic large-cell lymphoma. N Engl J Med 1986, 314, 943-948.

4. Orwat D.E., Batalis N.I.: Intravascular large B-cell lymphoma. Arch Pathol Lab Med 2012, 136, 333-338.

5. Au W.Y., Shek W.H.., Nicholls J., Tse K.M., Todd D., Kwong Y.L.: T-cell intravascular lymphomatosis (angiotropic large cell lymphoma): association with Epstein-Barr viral infection. Histopathology 1997, 31, 563-567.

6. Wu H., Said J.W., Ames E.D., Chen C., McWhorter V., Chen P., et al.: First reported cases of intravascular large cell lymphoma of the NK cell type: clinical, histologic, immunophenotypic, and molecular features. Am J Clin Pathol 2005, 123, 603-611.

7. Ponzoni M., Arrigoni G., Gould V.E., Del Curto B., Maggioni M., Scapinello A.: Lack of CD 29 (beta1 integrin) and CD 54 (ICAM-1) adhesion molecules in intravascular lymphomatosis. Hum Pathol 2000, 31, 220-226.

8. Kato M., Ohshima K., Mizuno M., Kyogoku M., Hashikawa K., Tokura Y., et al.: Analysis of CXCL9 and CXCR3 expression in a case of intravascular large B-cell lymphoma. J Am Acad Dermatol 2009, 61, 888-891.

9. Kinoshita M., Izumoto S., Hashimoto N., Kishima H., Kagawa N., Hashiba T., et al.: Immunohistochemical analysis of adhesion molecules and matrix metalloproteinases in malignant CNS lymphomas: a study comparing primary CNS malignant and CNS intravascular lymphomas. Brain Tumor Pathol 2008, 25, 73-78.

10. Fonkem E., Lok E., Robison D., Gautam S., Wong E.T.: The natural history of intravascular lymphomatosis. Cancer Med 2014, 4, 1010-1024.

11. Zuckerman D., Seliem R., Hochberg E.: Intravascular lymphoma: the oncologist's “ great imitator". Oncologist 2006, 11, 496-502.

12. Yoon S.E., Kim W.S., Kim S.J.: Asian variant of intravascular large B-cell lymphoma: a comparison of clinical features based on involvement of the central nervous system. Korean J Intern Med 2019, 35, 946-956.

13. Brunet V., Marouan S., Routy J.P., Hashem M.A., Bernier V., Simard R., et al.: Retrospective study of intravascular large B-cell lymphoma cases diagnosed in Quebec: a retrospective study of 29 case reports. Medicine (Baltimore) 2017, 96 , e5985.

14. Satoh S., Yamazaki M., Yahikozawa H., Ichikawa N., Saito H., Hanyuu N., et al.: Intravascular large B cell lymphoma diagnosed by senile angioma biopsy. Intern Med 2003, 42, 117-120.

15. Wolter M., Badoual C., Wechsler J., Lambolez T., Haioun C., Bouloc A., et al.: Intravascular large cell lymphoma revealed by diffuse telangiectasia and cauda equina syndrome. Ann Dermatol Venereol 2002, 129, 320-324.

16. Phoon Y.W., Lin X., Thirumoorthy T., Tan S.Y., Lee H.Y., Lim S.T., et al.: Intravascular large B-cell lymphoma presenting as panniculitis clinically: a case report. Singapore Med J 2018, 59, 163-164.

17. Maiolo C., Ibbetson S.J., Sidhu S.K., Kearney D.: Intravascular large B-cell lymphoma presenting as panniculitis. JAAD Case Rep 2017, 6, 536-538. 
18. Herrscher H., Blind A., Freysz M., Cribier B., Mahé A.: Intravascular lymphoma simulating relapse of breast cancer: an original clinical case. Ann Dermatol Venereol 2019, 146, 292-296.

19. Ozgüroğlu E., Büyülbabani N., Ozgüroğlu M., Baykal C.: Generalized telangiectasia as the major manifestation of angiotropic (intravascular) lymphoma. Br J Dermatol 1997, 137, 422-425.

20. Ponzoni M., Campo E., Nakamura S.: Intravascular large B-cell lymphoma: a chameleon with multiple faces and many masks. Blood 2018, 132, 1561-1567.

21. Alon R., Shulman Z.: Chemokine triggered integrin activation and actin remodeling events guiding lymphocyte migration across vascular barriers. Exp Cell Res 2011, 317, 632-641.

22. Miyake Z., Tomidokoro Y., Tsurubuchi T., Matsumura A., Sakamoto N., Noguchi M., et al.: Intravascular large B-cell lymphoma presenting with hearing loss and dizziness: a case report. Medicine (Baltimore) 2019, 98, e14470.

23. Pothen L., Aydin S., Camboni A., Hainaut P.: Nephrotic syndrome without kidney injury revealing intravascular large B cell lymphoma. BMJ Case Rep 2019, 12, e229359.

24. Patel S., Li Y., Berchuck J.E., Cunningham J., Kim A., Pozdnyakova O.: Did you "miss" me? A subtle case of intravascular large B-cell lymphoma. Am J Hematol 2019, 94, 162-163.

25. Ronny F.M.H., Black M.A., Arbini A.A.: Intravascular large B-cell lymphoma with multi-organ failure presenting as a pancreatic mass: a case with atypical presentation and definite diagnosis post-mortem. Autops Case Rep 2017, 7, 30-36.

26. Kusunoki R., Fujishiro H., Yoshimura M., Sawada K., Suemitsu S., Kataoka M., et al.: Intravascular large B-cell lymphoma mimicking hepatobiliary infection: a case report and literature review. Intern Med 2019, 58, 1885-1889.

27. Aouba A., Diop S., Saadoun D., Trebbia G., Vilde F., Patri B., et al.: Severe pulmonary arterial hypertension as initial manifestation of intravascular lymphoma: case report. Am J Hematol 2005, 79, 46-49.

28. Fordham N.J., O'Connor S., Stern S., Nikolova V., Bain B.J.: Circulating lymphoma cells in intravascular large B-cell lymphoma. Am J Hematol 2017, 92, 311.

29. Balakrishna J.P., Jones D.: A young woman with intravascular large B-cell lymphoma in a benign-appearing endometrial polyp. Blood 2019, 133, 1920.

30. Kawai S., Okuda T., Fukui A., Sanada Y., Yoshikawa K., Morikawa M., et al.: Intravascular lymphoma presenting as a cavernous sinus tumor. Intern Med 2019, 15, 58.

31. Matsue K., Abe Y., Narita K., Kobayashi H., Kitadate A., Takeuchi M., et al.: Diagnosis of intravascular large B cell lymphoma: novel insights into clinicopathological features from 42 patients at a single institution over 20 years. Br J Haematol 2019 , 187, 328-336.

32. Fozza C., Bonfigli S., Conti M., Dore F., Longinotti M.: Long-lasting fever of unknown origin preceding the diagnosis of intravascular lymphomatosis: a further case stimulates some remarks. Am J Hematol 2003, 74, $211-213$.

33. Devitt K.A., Gardner J.A.: Intravascular large B-cell lymphoma: the great imitator. Autops Case Rep 2018, 30 , e2018055.

34. Asada N., Odawara J., Kimura S., Aoki T., Yamakura M., Takeuchi M., et al.: Use of random skin biopsy for diagnosis of intravascular large B-cell lymphoma. Mayo Clin Proc 2007, 82, 1525-1527.

35. Matsue K., Abe Y., Kitadate A., Miura D., Narita K., Kobayashi H.: Sensitivity and specificity of incisional random skin biopsy for diagnosis of intravascular large B-cell lymphoma. Blood 2019, 133, 1257-1259.

36. Matsue K., Asada N., Odawara J., Aoki T., Kimura S., Iwama K., et al.: Random skin biopsy and bone marrow biopsy for diagnosis of intravascular large B cell lymphoma. Ann Hematol. 2011, 9, 417-21.

37. Cho H.G., Sheu S.L., Kuo K.Y., Ally M.S., Bailey E.E., Kim J., et al.: Limited role of random skin biopsy in the diagnosis of intravascular lymphoma in adult patients with hemophagocytic lymphohistiocytosis. Acta Haematol 2017, 138, 33-38.

38. Suehara Y., Sakata-Yanagimoto M., Hattori K., Nanmoku T., Itoh T., Kaji D., et al.: Liquid biopsy for the identification of intravascular large B-cell lymphoma. Haematologica 2018, 103, e241-e244.

Received: 19.07 .2020

Accepted: 31.08 .2020

Otrzymano: 19.07.2020 r.

Zaakceptowano: $31.08 .2020 \mathrm{r}$.

How to cite this article

Odziomek A.M., Jarliński P., Rebizak E., Węgłowska J.: Intravascular large B-cell lymphoma. Dermatol Rev/Przegl Dermatol 2021, 108, 46-51. DOI: https://doi.org/10.5114/dr.2021.105893. 